\title{
The Growth and Expansion Path of BYD Company Limited and its Innovation Model $^{*}$
}

\author{
Hongmei Zheng \\ School of Economics, \\ Shenzhen Polytechnic, \\ Shenzhen, Guangdong, P.R. China, \\ hongmei@szpt.edu.cn \\ Yang Cong-kun \\ School of Economics, \\ Shenzhen Polytechnic, \\ Shenzhen, Guangdong, P.R.China, \\ yxd79@szpt.edu.cn
}

\author{
Mou Tong-hua \\ School of Management, \\ Shenzhen Polytechnic, \\ Shenzhen, Guangdong, P.R. China \\ thmu@szpt.edu.cn
}

\author{
Du Fang* \\ School of Economics, \\ Shenzhen Polytechnic, \\ Shenzhen, Guangdong, P.R.China \\ *Corresponding author, dufang_63@hotmail.com
}

\begin{abstract}
This article is themed with the study of the leap-forward development paths and independent innovation patterns of BYD, aimed to search for its main innovative elements and restraint factors that form various bottlenecks so as to provide the small-and-medium-sized private enterprises with experiences for leap-forward growth. Firstly, it analyzes the growth paths of $\mathrm{BYD}$, and then makes comparisons between BYD's innovative modes and general corporate patterns, and applies transaction cost analytic approach to study the innovative elements like "vertical integration" of the supply chain, "branch network channel" of marketing strategies and the market strategy of "turning the second-tier and third-tier cities into first-tier ones", achieving transaction cost leadership; since 2010, BYD has come across various bottlenecks, and the transaction cost of original pattern has reached a critical point. Therefore, the enterprise needs to break through the original mode, and try innovative patterns. The author has put forward that it is necessary to carry out adjustment of development strategies, proper exit of the strategy of vertical integration as well as the organization of product structure; conduct independent $R \& D$, and master core technologies to create its own brand; engage in open innovations, while applying internal and external complementary resources to achieve further innovation, and other viewpoints.
\end{abstract}

Keywords-BYD; growth path; innovation model; SMEs

\section{Why BYD IS CHOSEN FOR CASE STUDY?}

A. It Witnessed the Course of Rapid Growth of China's SMEs Since the Reform and Opening Up

In the past decade, product diversity, in combination with international diversity, has become an increasingly important strategy among small and medium-sized technology-based enterprises (SMTEs) [1]. Founded in February 1995, BYD Company Limited has developed, in less than 20 year, from a small battery enterprise with an investment of RMB 2.5 million and 20 employees to a world-class high-tech enterprise that owns more than
200,000 employees and 9 production bases across China, including Guangdong, Beijing, Shanghai, Changsha, Ningbo and Xi'an, has subsidiaries or offices in United States, Europe, Japan, South Korea, India, Taiwan, Hong Kong and other countries and regions, and boasts three industrial clusters including IT, automobile and new energy $[2,3]$. Like many other Chinese SMEs, BYD has grown, ever since the reform and opening up, from small to large, from weak to strong and finally becomes a world-renown and influential big enterprise and brand name. BYD has realized growth in a relatively short period of time which it takes western enterprises a hundred years to achieve, witnessed the course of growth of Shenzhen's enterprises that are on the forefront of reform and opening up, and created the "BYD Myth" [4].

B. Wang Chuanfu Has Embarked on a Road of Entrepreneurship from a Grassroots Businessman to a Successful Entrepreneur

Wan Chuanfu set up BYD as a technical worker and the company started with the import \& export business of battery parts and components. BYD experienced the primary stage of battery assembly production of key battery parts and components: in 2003, BYD ranked the first in the world in the field of nickel-cadmium battery, the second in nickel-hydrogen batteries, the third in lithium battery and became the second largest producer of rechargeable battery in the world. After that, Wan Chuanfu seized the opportunities from the development of Chinese auto markets and boldly entered the auto industry [5]. He was not copying the development mode of other auto companies. Rather, with amazing audacity, wisdom and hard work, he successfully brazed a trail of innovation featuring independent $\mathrm{R} \& \mathrm{D}$, production and brand by an auto-producing enterprise. While accelerating the pace of commercialization of electric car in recent years, Wan Chuanfu has focused on battery energy storage station, solar power plant, photovoltaic cell and LED with a view to 
taking a leading position in the fields of new energy in the future. In only more than 10 years, BYD's assets have increased by tens of thousands of times with amazing development momentum and created the miracle of SMEs' growth and expansion [6]. In 2010, BYD was rated the eighth among the Top 50 Global Innovative Enterprises and the first among the Top 100 Global Technological Enterprises [7], and Wan Chuanfu topped Forbes China Rich List 2009 in the Mainland with RMB 35 billion of personal assets [8].

To a certain extent, the success of BYD is the success of Wan Chuanfu; the entrepreneurial spirits he has are the decisive factors for the success of his enterprise-adventure, persistence, dedication, cooperation, learning and good faith. $\mathrm{He}$ also represents the quintessence of the success of China's grassroots entrepreneurs to a certain extent: in such a hot land of reform and opening up as China, seize opportunities that have not been discovered by others, take advantage of resources that can't be utilized by others and find methods that are hardly imaginable by ordinary people. It is especially important to avoid blindly introducing managerial methods from abroad, but rather, to closely integrate the advanced managerial theories and practical experience of the world with the actual domestic conditions of China at that time, and face up to the volatile market environment with far-sighted strategies and flexible tactics at any time, boldly emancipate the mind, have the courage to challenge authority, explore a distinctive path of developing and strengthening of China's SMEs.

C. The Innovation Model of Enterprise Growth and Expansion path Greatly Narrows the Gap with the Forthgoers

The Fig. 1 shows the growth and expansion path of BYD from the initial starting to developing three industrial clusters including IT, auto, and new-energy, as well as the overall layout of the enterprise. We can see that there exists progressive and parallel relationship among the three industrial clusters: the so-called progressive relationship can be seen mainly in the early or late stages of enterprise development, which shows the extension and integration of industry chain, in which the former industry chain provides technological reserve and reference of development mode for the latter one; while the so-called parallel relationship shows mutual balancing and supporting of the whole industry and the Polymerization Effect of all businesses. It is the innovation systems that accompany the growth, development and strengthening of the three industrial clusters. Wang Jianjun, the press spokesperson of BYD said: "the high-speed development of BYD is owed to the all-dimensional innovation of technologies, markets and production flow". BYD's innovation in a series of links including $\mathrm{R} \& \mathrm{D}$, business operation, management and training of talented personnel have greatly shortened the time of growth as ordinary enterprises in the same industry and narrow the gap with advanced enterprises of the world, and completed the transformation from a small enterprise to a successful one with state-of-the-art technologies and managerial expertise in a relatively short period of time.
BYD is the representative and model among many of China's successful SMEs.

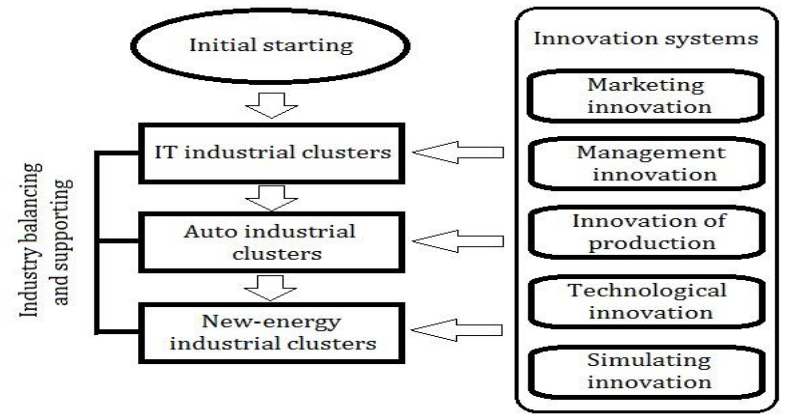

Figure 1. Growth and expansion path of BYD

D. Development Bottleneck During Continuous Development and Strengthening of the Enterprise

To some extent, SME's technological innovation capacity lies in regional development level for example region policy, legal system, capital and labor force ${ }^{[9]}$. Like many Chinese enterprises, due to volatile international and domestic environment as well as inherent bottleneck restrictions of enterprise during the course of its development, BYD has suffered the toughest difficulties in its course of growth since 2010, and sales and profits have continuously dropped: the net profits of 2010 dropped by $33.5 \%$ to RMB 2.523 billion compared with the same period of the previous year, while that of the first half of 2011 even dropped dramatically by $88.6 \%$ to RMB 275 million, plunging the enterprise in crisis[10]. The current plight is testing the core innovation systems, enterprise culture and management concepts that the enterprise relies on to survive, and thus posing a new problem: how to maintain continuous development of the enterprise? This has also created good opportunities for us to analyze the growth of SMEs in a comprehensive and dialectic manner.

\section{BYD's GROWTH AND EXPANSION PATH AND ITS CHARACTERISTICS}

\section{A. Development Course of BYD}

The first stage: IT industry of BYD

1997: Began manufacturing Li-ion battery;

1998: BYD Europe B.V. founded;

1999: Production of nickel-cadmium batteries reached 150 million in quantity, independently researched and developed the advanced SC2100P large-current discharging batteries, and founded BYD (HK) Co., Ltd and BYD America Corp.

2000: Became the first Li-ion battery supplier to Motorola.

2001: Production of nickel-cadmium batteries reached 250 million in quantity, independently researched and developed the process of high-performance foamed nickel welding, anode edge welding, and founded BYD Korea Office.

2002: Became the first Li-ion battery supplier to Nokia and Listed on the Hong Kong Stock Exchange Main Board. 
The second stage: Auto industry of BYD

2003: Acquired Xi'an Tsinchuan Auto Co., Ltd. (now BYD Auto Co., Ltd.) and officially entered the fields of auto manufacturing and marketing;

2005: the first BYD F3 automobile with independent brand hit the market and BYD Japan Co., Ltd was founded.

2006: F3e, the pure electric car, was developed successfully;

2007: BYD Electronics India Private Limited was founded and annual sale of 101,000 automobiles was realized that year; the prizes of "Top Production Increase", "Top Sale Increase" and "Top Sale of Single Product" were won in a row, thus it became the fastest-growing mainstream auto enterprise of China.

2008: BYD purchased the Sino MOS Semiconductor (Ningbo) Inc. and achieved annual product sale of 171,000 automobiles. BYD F3DM, the world's first dual mode electric car, hit the market in Shenzhen and Warren Buffett purchased $10 \%$ of BYD's shares with RMB 230 million;

2009: Acquired Sanxiang Coach of Hunan Midea Coach;

2010: BYD North American Headquarters was founded and $18 \%$ equity of Tibet Zabuye Lithium Industry Co., Ltd was purchased, and the parent company of Mercedes-Benz, Daimler AG signed a contract of cooperation with BYD.

2011: Delivered 200 electric buses and 250 electric taxies to Shenzhen Public Transportation System [3,11].

\section{B. Growth Curve of BYD(Fig.2 \& Fig.3)}

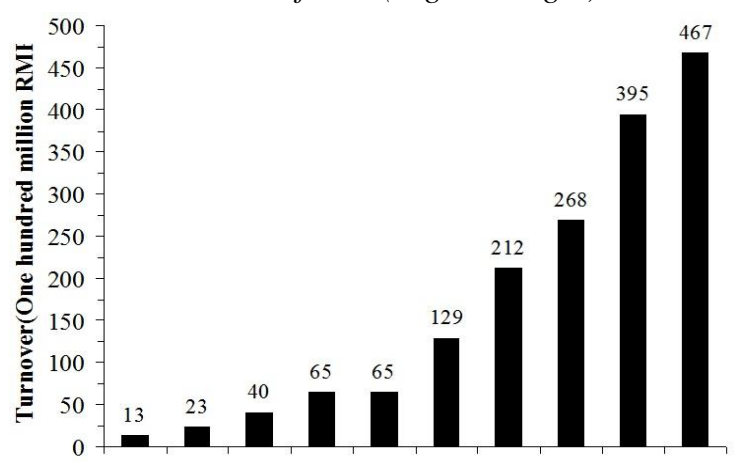

2001200220032004200520062007200820092010 Year

Figure 2. Growth output value of BYD

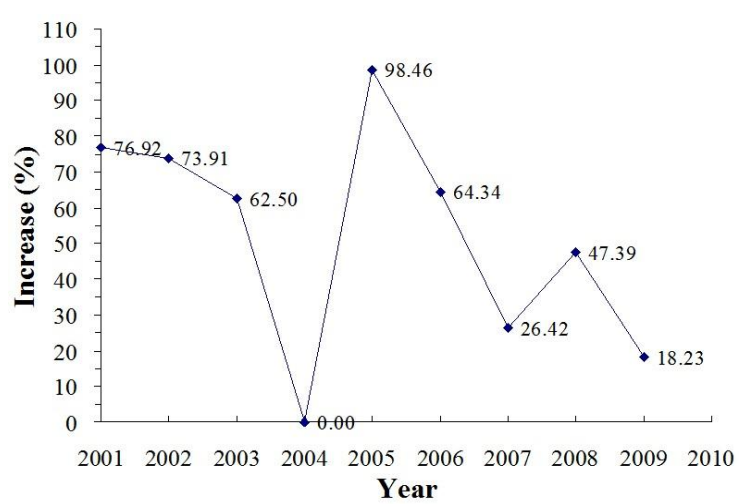

Figure 3. Growth curve of BYD

\section{BYD's Growth and Expansion Path and Its}

Characteristics

\section{1) Growth Path of BYD}

BYD's development path is the process of enterprise growth which reflects the growth positioning, directions and strategies of the enterprise.

The first stage: Initial starting (1995-1997), the primary stage of the enterprise(Fig. 4). BYD mainly conducted import \& export business of battery parts and components, battery assembly, and production of key battery parts and components. The scale was small and the business was single.

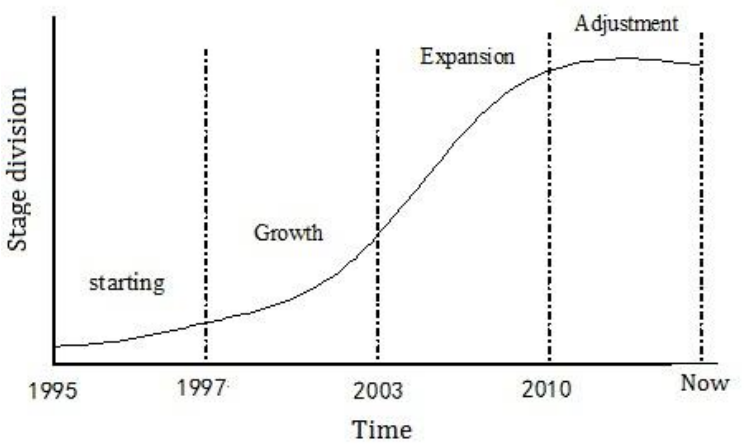

Figure 4. Growth tendency of BYD

The second stage: Growth (1997-2003), the stage of rapid growth and expansion of the enterprise. It can be seen from the rapid expansion of production scale, product categories, regional space and business profit. By 2003, BYD had become the second largest producer of rechargeable battery in the world, and ranked the first, the second and the third in the world in terms of nickel-cadmium battery, nickel-hydrogen batteries, and lithium battery respectively.

The third stage: cross-industry expansion (2003-2010); in this stage, BYD seized the good opportunities of China's auto markets, entered the auto industry and became the fastest-growing mainstream auto enterprise of China.

The fourth stage: Adjustment (from 2010 till now); in this stage, BYD entered the year of adjustment starting from 2010. It greatly reduced marketing staffs and made optimized adjustment in operation mode, brand, organizational structure and management of talented personnel, etc [12].

We visualized the growth and expansion path of BYD as follows based on the above four stages: the growth of BYD is an upward curve, the inclination rate of which represents expansion speed of the enterprise in different stages. The growth rate of the enterprise in the primary stage is pretty slow. With accumulation of energy, it enters the growth stage and the expansion quickens. Through innovation, the enterprise develops new space of growth and continues to maintain the momentum of high-speed growth, but the development speed drops dramatically after entering the adjustment period.

2) Independent Innovation Patterns of BYD

Innovation model refers to the choice of path to 
implement innovation. The Study of Technological Innovation divides the innovation model into three categories: Independent Innovation, Imitative Innovation and Collaborative Innovation [13, 14].

It is independent innovation patterns of the enterprise that accompanies the growth and expansion of BYD as shown in the figure below.

a) Objectives and directions of innovation patterns: Continuously discover, satisfy and create customer demand, and maximizing the commercial value of innovation factors in the market is the objective and direction of BYD's constant innovation.

b) Foundation and starting points of innovation patterns: Simulating innovation: in the initial starting stage of enterprise and the development pattern of products, conducting research, assimilation, copying and drawing upon with successful technologies, products, manufacturing process and development pattern as the "model" in an effort to reduce risks for business startup and maximize the startup efficiency of the enterprise. Simulating, studying and drawing upon are the fastest shortcut of business startup. The F3 model that creates sales miracle is exactly BYD's simulation of COROLLA of TIANJIN FAW TOYOTA MOTOR.

Only by simulating is impossible to bring about sales miracle; innovation on the basis of simulating is the core and key factors of the enterprise. BYD's innovation in simulating is discovering and satisfying special demands of the customers, and maximizing the commercial value of the prototype. The F3 model satisfies the customers' affection on COROLLA of TOYOTA on the one hand while greatly reduces the costs on the other hand, which is within the purchasing power of the customers and thus sold well.

Simulating innovation is the mode that deserves to learn and draw upon in the growth and expansion path of SMEs.

c) Strategies of innovation patterns: Overall cost leadership

The theory of Five Forces Model put forward by Michael E. Porter in the 1980s has a profound impact on the formulation of enterprise strategies, in which overall cost leadership is one enterprise strategy that BYD has always been implementing and executing.

In Michael E. Porter's view, competition of enterprises exists not only among the original rivals, but also among upstream suppliers, downstream distributors, potential new entrants, etc. When an enterprise is driven to lower market transaction costs, it will integrate resources in a vertical manner, and develops, expands and extents upstream and downstream. BYD achieves independent design, R\&D and production of $70 \%$ of parts and specialized instruments and equipment in the enterprise by taking advantage of "vertical integration" and makes the most of resources, saves the costs and creates BYD products' advantages in cost performance $[15,16]$.

Costs advantages are the primary driving force of an enterprise's resources integration and expansion to upstream and downstream enterprises. It is also the general guideline for an enterprise to conduct management innovation, technological innovation and organizational innovation, etc.

d) Major innovation modules:Technology innovation: it is deemed by endogenous economic growth theory that the technology innovation is the source of economic growth[17]. Innovation can take place by chance if a supportive environment and culture are absent. "Technology is the trump card while innovation is the foundation" [18, 19]. In BYD's innovation patterns, technological innovation is the core and the lasting driving force of maintaining the competitive edge of the enterprise (Fig.5).

Process innovation: the working procedure of "human + machinery" is BYD's remaking of production flow according to its actual conditions, which is pretty original and creative. The whole production line is divided into several workshops, and each workshop is divided into several simple and easily operable working procedures, and each working procedure can be finished by "human + machinery".

e) Marketing innovation: Marketing innovation: BYD's marketing strategy mainly consist of management tactics of branch network channel "one brand with four sales network" ; accurately segment the market, focus on one province and then spread the strategy; start with those small-and-medium-size cities and then transfer to large-size cities and high-end markets.

Cross-industry transplant: transplant the modes that take shape during the R\&D and production of cell phone battery completely to the production of automobiles and utilize it flexibly, which bring huge success to BYD.

To sum up, we summarize the innovation patterns of BYD as: with creating customer demand and achieving the commercial value of innovation factors as the objective, with simulating innovation as the starting point and foundation of innovation patterns of the enterprise, and with technological innovation as the core to constantly innovate the enterprise in all aspects according to the strategy of overall cost leadership. 


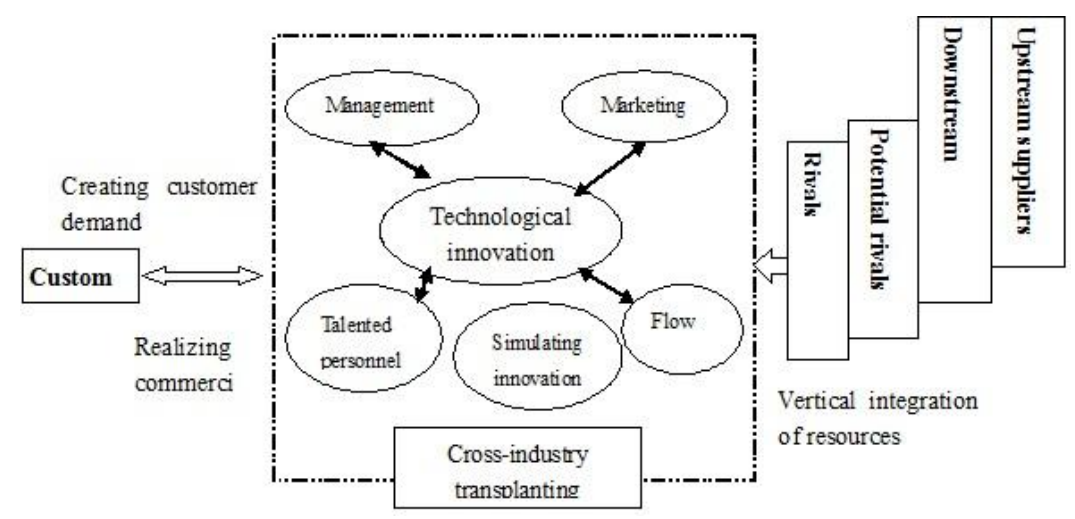

Figure 5. Driving force of innovation

\section{GROWTH AND EXPANSION PATH FOR BYD's INNOVATION AND ITS RESTRICTIVE FACTORS}

Achieving leapfrog development through independent innovation is the core of BYD's growth and expansion. However, BYD also come across bottleneck on the development road after rapid growth. BYD's innovation and restriction factors can be summarized as shown in Table 1 .

\section{COST ANALYSIS OF BYD'S INNOVATION PATTERNS}

According to Oliver. E. Williams, the major objectives and functions of all systems are saving transaction costs. The transaction cost is of all cost relevant with the establishment, transition and application of system or organization. A transaction shall be completed with the optional governance structure requiring the lowest transaction costs [20]. BYD's innovation patterns achieve optimal control of the enterprise's transaction costs through some innovation patterns including vertical integration of resources. It not only shows obvious advantages in a certain phase of the enterprise's development, but also meets bottleneck in the subsequent development and expansion. We will make transaction cost analysis by comparing BYD's innovation patterns:

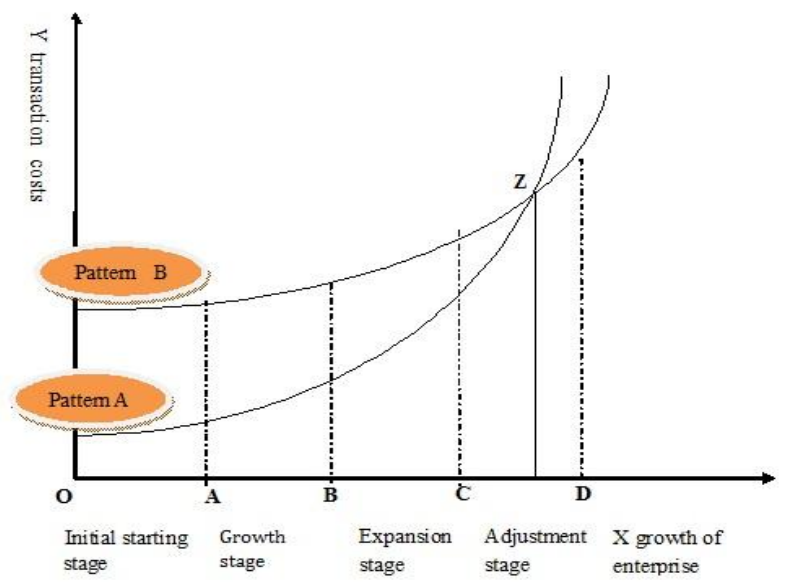

Figure 6. Evolutionary trend of the transaction costs
First we assume that BYD's new innovation pattern is Pattern A. This mode realizes the leadership of transaction via "Vertical Integration" on the supply chain, "branch network channel" on the marketing policy and "Being specialized in first city from secondary and third cities" market policy. While the conventional pattern of peer enterprises is Pattern B as shown in Fig. 4: the $\mathrm{X}$ axis represents the growth path of enterprises, and it is divided into Initial starting stage (OA interval), Growth stage ( $\mathrm{AB}$ interval), Expansion stage (BC interval), and Adjustment stage (CD interval). The increase of $X$ represents that the enterprises are gradually turning to matured stage from the initial stage, with operation scales gradually expanding and management complexity increasing. The $\mathrm{Y}$ axis represents the transaction costs of enterprises which means relevant costs required in the establishment, implementation and development of enterprise innovation pattern.

It can be observed from Fig. 6 that:

a. The costs of initial investment in Pattern A are significantly lower than those of Pattern B.

On initial stage, BYD AUTO decomposes the production line as several working procedures completed by manual work to replace the machine as much as possible, and the semi-automatic and semi-manual production flow is created exclusively. The investment cost for this kind of production flow is $1 / 2$ even $1 / 4$ of enterprises with Mode B in same industry. For instance, BYD AUTO eliminates the Japanese production line that the purchase cost exceeds RMB 1000 and 10000 as well as higher maintenance cost on the battery assembling and production link. Under the condition of guarantying the product quality, the manual reformation is performed and the guarantee for product quality is realized by employing the fixture. Due to cheap labor force in China, the cost of batteries assembled via manual production line is greatly lower than the one of similar enterprises, being 20\%-30\% cheaper than similar products in Japan.

Not only the primary investment is small but also the flexibility is great for this kind of production line giving priority to manpower solely created by BYD AUTO not only. When a new product is pushed out, the local adjustment for key links is only required for existing production line and then the corresponding technical training for employees shall be conducted. It is compared 
with Mode B that the fixed cost of Mode A as well as the renovation and transformation cost of equipment are saved; in addition, the cost of labor force is cheaper so as to realize the advantage of cost leadership.

b. "Vertical Integration "for Mode A of BYD AUTO indicates that the enterprise completely integrates the design, research and development as well as production for complete machine and spare parts of certain kind of product. Within the scope of enterprise, the production and supply for each spare part provide the supply scheme of integral products for clients [2]. Cost advantage of this kind of mode: the price comparison advantage is formed via self-control as well as research and development of upstream products and transmitted onto the additional value of end products.

At the beginning of development for automobile industry, BYD AUTO duplicates the vertical integration mode of battery production: purchase the mould factory to substantially lower the mould cost; voluntarily develop and manufacture the key spare parts and special instruments and equipments to realize the self-control for mould of whole automobile, interior fittings and welding production line used for automobile manufacturing, coating production line and special CNC machine tool used for engine. It is calculated according to total cost that $70 \%$ of BYD car is manufactured by itself to effectively save the production cost and realize the core concept of low price with same functions by manual and self-made equipment replacing the production line with over RMB100 millions.

It can be observed from Figure 6 that, either at the initial stage $\mathrm{OA}$ when the batteries are produced or at stage $\mathrm{AB}$ and $\mathrm{BC}$ when the automobile field ad new energy field are entered, Curve A is lower than Curve B to show that Mode $\mathrm{A}$ is always provided with the advantage of cost leadership in this interval. Meanwhile, we also observe that, although Curve $\mathrm{A}$ is lower than Curve B, the gradient of Curve A increases gradually and the marginal cost is obviously greater than the one of Mode B; this also shows that the transaction cost advantage of outsourcing strategy for Mode $\mathrm{B}$ is shown gradually along with expansion of enterprise of enterprise scale; while the cost advantage value brought by vertically integrating the upstream and downstream resources decreases gradually.

$c$. It can be observed from Figure 6 that the point of intersection of the two curves $\mathrm{Z}$ is a critical point. When $\mathrm{X}<\mathrm{Z}$, the transaction costs of Pattern $\mathrm{A}$ is lower than those of Pattern B during the same growth period of the enterprise; when $X>Z$, the transaction costs of Pattern A is much higher than those of Pattern B.

The disadvantage of vertical integration mode lies in that the cost advantage of products formed upstream can't be realized when the product demand downstream is insufficient, meanwhile, each selling cost, labor cost and administration expense cost can't be shared on each link of industrial chain. The intersection $\mathrm{Z}$ shows that the enterprise enters into the disadvantage stage of vertical integration, this stage for BYD appeared in 2010. With rapid expansion of enterprises, the sales cost of enterprise is too high, the labor cost is too high and the product demand downstream is insufficient so that the operating produces the bottleneck.
At the beginning of 2010, BYD AUTO began to implement the "Thousand Store Project" on the marketing network, including that the covering rate of selling network towards provincial cities reaches $100 \%$, with over $80 \%$ in prefectural-level cities and over $70 \%$ in county-level cities, including 900 for total branch websites and 8 customer service centers, providing the distribution of accessories and technical support. Meanwhile, the personnel configuration in each region also swells simultaneously. The expansion of marketing network brings about the substantial improvement of sales cost. In 2010, the sales cost increased in RMB 7.516 billion to be higher than RMB 7.216 billion for increase value of revenue, meanwhile, the cost of employees also increased continuously. In 2009, the quantity of employees in BYD AUTO was of 160000, the total of employee cost within this year covered about $11 \%$ of group turnover. Until 2010, the quantity of employees in BYD AUTO exceeded 180000; the salary cost was up to $14.39 \%$. Until first half of 2011 , the quantity of employees in BYD AUTO was up to 185000 , even the covering ratio was up to $17.26 \%$.

If the demand downstream is still powerful and the sales volume reaches the sales target throughout the year, the cost advantage of vertical integration still exists. It is a pity that the sales volume of BYD in 2010 produced the great shrinking so that each cost of company can't be shared and the cost rate rises. The integral profit fluctuation is greater than the one of automobile enterprises globally to indicate that the transaction cost of Mode A begins to be greater than the one of Mode B.

We draw the following conclusions based on the above analysis of enterprise transaction costs:

$a$. The enterprise innovation patterns achieve evident effects in BYD's initial starting stage and growth stage. Thanks to China's enormous and cheap labor resources, the initial investment of this pattern is obviously lower than those production enterprises that rely on automatic production lines. Meanwhile, semi-manual and semi-automation can bring more technological flexibilities, which undoubtedly greatly reduce the input of costs of fixed assets and lower the transaction costs of the enterprise.

$b$. In the expansion period of auto industry, it takes advantage of innovative industry transplant, vertical integration of resources and thus enjoys cost advantages.

$c$. With the development of the enterprise and the development of peer upstream and downstream enterprises, transaction costs among different subjects in the industry chain gradually drop. The costs advantages of BYD from vertical integration gradually decrease and the comparative advantages are no more prominent.

$d$. The bottleneck during the course of development from 2010 and the transaction costs of original pattern reach the critical point; the enterprise needs to abandon the original pattern to make new attempts and innovation of new patterns. 
TABLE I. INNOVATION AND RESTRICTION FACTORS FOR BYD

\begin{tabular}{|c|c|c|c|}
\hline \multicolumn{2}{|r|}{ Innovative factors } & \multicolumn{2}{|r|}{ Restrictive factors } \\
\hline $\begin{array}{l}\text { Entrepreneur } \\
\text { spirits }\end{array}$ & $\begin{array}{l}\text { Wang Chuanfu is equipped with convincible professional } \\
\text { technological expertise, unique strategic vision and } \\
\text { leadership, the insight to seize opportunities decisively and } \\
\text { the adventure quality to accept challenges }\end{array}$ & $\begin{array}{l}\text { Disadvantage of } \\
\text { centralized } \\
\text { structure }\end{array}$ & $\begin{array}{l}\text { BYD adopts divisional system in the } \\
\text { organizational structure. Wang Chuanfu is the } \\
\text { president and chairman of board of BYD and } \\
\text { manages more than } 20 \text { business departments. } \\
\text { Thus his power is excessively centralized. }\end{array}$ \\
\hline $\begin{array}{l}\text { Ability of } \\
\text { technological } \\
\text { innovation }\end{array}$ & $\begin{array}{l}\text { 1. R\&D team: it has a R\&D team of } 20 \text { thousand people, } \\
\text { and establishes more than ten research institutes including } \\
\text { Central Research Institute, Auto Engineering Research } \\
\text { Institute, Electric Power Research Institute, etc } \\
\text { 2. R\&D of core technology: it has independent R\&D } \\
\text { experience and data accumulation of multiple products and } \\
\text { its technological development platform with distinctive } \\
\text { features. }\end{array}$ & $\begin{array}{l}\text { Restriction of } \\
\text { investment costs } \\
\text { of technology } \\
\text { R\&D }\end{array}$ & $\begin{array}{l}\text { The proportion of employee costs in operating } \\
\text { revenue rises year after year in recent years. } \\
\text { But the proportion of } \mathrm{R} \& \mathrm{D} \text { costs in } \\
\text { operating revenue is dropping year after year }\end{array}$ \\
\hline IPR strategy & $\begin{array}{l}\text { It has scientific IPR planning and operation strategies, } \\
\text { flexibly uses ordinary license, exclusive permission, sole } \\
\text { license, cross licensing and other ways of licensing to } \\
\text { promote the application and industrialization of patents so } \\
\text { as to maximize the value of patents. }\end{array}$ & $\begin{array}{l}\text { Insufficient core } \\
\text { technologies }\end{array}$ & $\begin{array}{l}\text { In the competition with world-class } \\
\text { enterprises, there exists a huge gap in the } \\
\text { R\&D of core technologies }\end{array}$ \\
\hline $\begin{array}{l}\text { Innovation of } \\
\text { development } \\
\text { mode }\end{array}$ & $\begin{array}{l}\text { Innovative simulating; research, assimilate, simulate and } \\
\text { restructure products of the same kind }\end{array}$ & $\begin{array}{l}\text { Lack of brand } \\
\text { advantage }\end{array}$ & $\begin{array}{l}\text { The simulated and restructured simulating } \\
\text { products have no advantage of brand }\end{array}$ \\
\hline $\begin{array}{l}\text { Combining } \\
\text { innovation of } \\
\text { patent and } \\
\text { non-patent } \\
\text { technologies }\end{array}$ & $\begin{array}{l}\text { Legally circumvents the existing patents, legally use } \\
\text { non-pattern technologies and independently develop its } \\
\text { own patterns. }\end{array}$ & $\begin{array}{l}\text { Lack of delicacy } \\
\text { in production } \\
\text { technologies }\end{array}$ & \\
\hline $\begin{array}{l}\text { Remaking of } \\
\text { production flow }\end{array}$ & $\begin{array}{l}\text { Restructure the production line: Divide the whole } \\
\text { production line into several workshops, and each workshop } \\
\text { is divided into several simple and easily operable working } \\
\text { procedures, and each working procedure can be finished by } \\
\text { "human + machinery". }\end{array}$ & $\begin{array}{l}\text { Restriction of } \\
\text { "Non-standard } \\
\text { and } \\
\text { semi-automatic" }\end{array}$ & $\begin{array}{l}\text { Non-standard and semi-automatic production } \\
\text { line can't meet the refined process } \\
\text { requirements of high-end products }\end{array}$ \\
\hline $\begin{array}{l}\text { Strategy } \\
\text { vertical } \\
\text { integration }\end{array}$ & $\begin{array}{l}\text { BYD achieves independent design, } \mathrm{R} \& \mathrm{D} \text { and production of } \\
70 \% \text { of parts and specialized instruments and equipment in } \\
\text { the enterprise and, through resources integration and } \\
\text { synergy effect, develop advantage in cost performance }\end{array}$ & $\begin{array}{l}\text { Strategies } \\
\text { vertical } \\
\text { integration }\end{array}$ & $\begin{array}{l}\text { The decreased demand of downstream markets } \\
\text { is fed back to the upstream through products, } \\
\text { thus apportioning the costs and impacting the } \\
\text { overall efficiency }\end{array}$ \\
\hline $\begin{array}{l}\text { Marketing } \\
\text { strategy }\end{array}$ & $\begin{array}{l}\text { 1.Channel management: branch network channel of "one } \\
\text { brand with four sales network" } \\
\text { 2. Accurately segment the market, focus on one province } \\
\text { and then spread the strategy. } \\
\text { 3. Start with those small-and-medium-size cities and then } \\
\text { transfer to large-size cities and high-end markets. }\end{array}$ & $\begin{array}{l}\text { The costs of sale } \\
\text { and distribution } \\
\text { are too high }\end{array}$ & $\begin{array}{l}\text { The sales network is expanding too fast, costs } \\
\text { of salespersons are too high, competition } \\
\text { among distributors become more intense and } \\
\text { the pressure is too high }\end{array}$ \\
\hline $\begin{array}{l}\text { Management } \\
\text { innovation }\end{array}$ & Copy matured modes to new industries & $\begin{array}{l}\text { Lack } \\
\text { professional } \\
\text { managers }\end{array}$ & $\begin{array}{l}\text { Overstaffing, practice nepotism, family-type } \\
\text { management structure }\end{array}$ \\
\hline
\end{tabular}

It can be concluded from the above analysis that: In light of the problems encountered during the course of development since 2010, BYD needs to draw lessons from the bitter experience, make adjustment of its development strategies, product mix and the development thinking; carry out management innovation, marketing innovation, financial innovation and brand innovation; improve its metabolism speed of absorbing and using knowledge technology, and create or expand the market of its new technology by widely using technology transfer[21]; change the centralized family-type management mode and appoint people on their merits; cut expenses on staffs and increase investment on technological R\&D and commit to technological upgrading and quality assurance; conduct independent $\mathrm{R} \& \mathrm{D}$, master core technologies and create brands that truly belong to itself; carry our open innovation, and meanwhile make use of the inside and outside complementary innovation resources to implement innovation. Open innovation has been proposed as a new paradigm for the management of innovation [21, 22]. The essence of open innovation is to absorb and use the outside innovation resource, and emphasize the SMEs' integration of inside and outside innovation resources [23]. Only in this way can it improve its competitiveness and get out of the plight.

\section{ACKNOWLEDGMENT}

This work is supported by the project of Philosophy and Social Sciences for 12th Five-Year Plan of Shenzhen (Grant No. 125B051) and the China- Australia Cooperation Foundation of Shenzhen Polytechnic (Grant No. 1).

\section{REFERENCES}

[1] D. R. Gnyawali and B. J. Park., "Competition and technological innovation in small and medium-sized enterprises: A multilevel conceptual model," Journal of Small Business Management, 2009, vol.47, pp. 308-330. 
[2] Tang Youping and Peng Lunan, "The BYD road to success brings the enlightenment on the small and medium--sized enterprises," Enterprise Vitality, 2008, 11.

[3] Research Documents of BYD in Oct. 2011.

[4] Ruan Jianfang, BYD Myth: Wang Chuanfu's Enterprising Life. Enterprise

a) Management Press, 2009.

[5] Company Profile BYD Official Site http://bydit.com/doce/about/ CompanyProfile/

[6] Jin Lvzhong, Guo Konghui and Li Gang, An Open-minded Independent Innovation Sample. A Research Report to Premier Wen Jiabao. 7, 2008.

[7] "The World's Most Innovative Companies 2010". Fast Company. Archived from the original on 19 April

[8] [8] Wang Chuanfu tops Forbes China Rich List 2009. People's Daily Online. November $\quad 05, \quad 2009$ http://english.peopledaily.com.cn/90001/90776/90882/6804813.html

[9] Qian Qinglan and Chen Yingbiao, "SME, Technological innovation and regional environment: the case of Guangdong, China," Procedia Earth and Planetary Science, 2011, pp. 327-333.

[10] "BYD Co Ltd 2012 Annual Report".

[11] Guangdong Federation of Industry \& Commerce, The blue book on the development of Guangdong's Private Enterprises, 2009 2010.

[12] BYD Co Ltd Company Brochure.

[13] He Peng, "Research on The Innovativeness of China's SMEs: In View of Growth.” Journal of Central South University, 2006.
[14] Fu Jiaji, Technology Innovation. Tsinghua University Press. 1998.

[15] Wang Huiying, Application Of Game Theory In The SMEs' Technology Innovation. China Economic Management. Second, 2007.

[16] Li Chunyan and Liu Lizhen, "Industrial innovation system production mechanism and structural model," Science of Science and Management of S.\& T. 1.2007.

[17] Romor, "Increasing returns and long-run growth," Political Economy, 1986, vol. 36 ,pp. 1002-1037.

[18] P. K. Ahmed, "Benchmarking innovation best practice," Benchmarking for Quality Management and Technology, 1998, pp. 45-58.

[19] P. Malaviya, "Innovation management in organizational context: an empirical study," Global Journal of Flexible Systems Management, 2005, 6(2), pp.1-14.

[20] E. W. Oliver, The Economic Institutions of Capitalism. The Commercial Press, 2002.

[21] H. Chesbrough. Open innovation: The new imperative for creating and profiting from technology[M]. Harvard Business School Press, Boston, MA. 2003

[22] O. Gassmann., "Opening up the innovation process: towards an agenda,” R\&D Management, 2006, 36(3),pp. 223-228.

[23] Cheng Yufen, "Improving the indigenous innovation capabilities in Chinese Enterprises through open innovation," Science of Science and Management of S.\& T. 4. 200 